\title{
The Role of Media in Enhancing Communicative Competence of the Learners at Tertiary Level - An Analytical Study
}

\author{
R. Abilasha ${ }^{*}$, M. Ilankumaran ${ }^{2}$ \\ ${ }^{l}$ Assistant Professor of English, Holy Cross College of Arts and Science (Autonomous), Nagercoil, Tamilnadu, India. \\ ${ }^{2}$ Professor of English, Noorul Islam Centre for Higher Education, Kumaracoil, Thuckalay, Tamilnadu, India. \\ E-mail:mikumaran@yahoo.com \\ *Corresponding authorE-mail: abilasharajan@yahoo.com
}

\begin{abstract}
Media is a channel through which every message is communicated using a language in a meaningful way. The language used in media can be said to be 'specific' and there arises a need to have the course -- Mass Communication Programme. Communicative competence means the capability to employ language effectively and aptly in social contexts and circumstances. Testing communicative competence is a challenging format by which the teachers assess the competence of learners. This includes information gap and role-play activities for speaking, letter writing, note-taking and summarising. The combination of all these enhance listening and writing competencies. An investigation has been conducted among the students to develop the communicative competence through media such as newspapers, internet, T.V, Radio etc. 50 respondents from two colleges, located in rural and urban areas, with 25 students each from a college, have been chosen for analysis. A questionnaire is used as a tool for the purpose of analysing communicative competence of the selected second year students of arts and science courses. This paper focuses on the importance of media in developing the language skills among the students at tertiary level.
\end{abstract}

Keywords: Media, language, communication, communicative competence, rural and urban, newspaper, radio, television, internet, analysis.

\section{Introduction}

English is a language of the world or the Lingua Franca. It is used to messages between people and countries. English language has reached and developed internationally, in such a way that it cannot be ignored. The use of English has dramatically increased in India. English Language Teaching (ELT) in India has not been able to bring about a change in the traditional teaching model implemented in most of the educational institutions. Pupils study English just to pass exam and teachers teach to complete this target assigned. The result is that students are not proficient in English to communicate successfully with others and students lack in communicative competence even at the tertiary level.

\subsection{Language}

Language reflects culture and tradition in general and all languages begin as 'speech' and employ different sentence structures to convey 'mood'. The language resources are word order, word form, syntactic structure, and 'intonation'. The primary aspect of any language is speech. The spoken from of the language is mostly used for communication. Speech consists of sounds, words and structures of sentence. "Language as a system of message uses sounds or symbols that enables us to express our feelings, thoughts, ideas, and experiences" (Goldstein, 2008).

\subsection{Communication}

Communication is a method of transferring information or messages. The term 'communication' has been derived from a Latin word 'commuicare' which means "to share"; it can be sharing of ideas, thoughts, messages, etc. According to Newman and summer "Communication is an exchange of facts, ideas, opinions or emotions by two or more persons" (Senapathi, 2010).

\subsection{Communication skills}

Communication skills implies the talent to convey and receive messages. The talent to communicate is the main factor. It distinguishes human beings from animals. It is the ability to communicate well. It differentiates one individual from another. It makes a person happy and successful social being. These habits keep on developing in human beings.

\subsection{Significance of communication skills}

Communication Skills help to improve all phases of human life from occupational life to social life of people. The skill to correspond information perfectly, obviously and as planned, is a fundamental life skill which should not be overlooked. It's never too late to labour on people's communication skills and thereby improving their quality of life. The significance of communication skills develops the ability to converse, pay attention, interrogate and write down with clearness and conciseness, which are important for leaders.

\subsection{Communicative competence}

Communicative competence is an idea introduced by Dell Hymes in 1966, later discussed and redefined by many authors. 'Communicative competence' is an expression in linguistics referring to a language user's grammatical knowledge of syntax, morphology, phonology and the like, as well as social knowledge 
about how and when to use utterances appropriately (Chomsky, Noam, 1965). It refers to a learner's ability to use language to communicate effectively. Canale and Swain in 1980 categorised competence in four areas:

- Linguistic

- Sociolinguistic

- Discourse and

- Strategic

Communicative proficiency means the ability to make use of a language effectively and correctly in social contexts and situations. Testing communicative competence is a testing format that teachers use to calculate their learners' ability. An investigation has been conducted among the students to develop the communicative competence through media using newspapers, internet, T.V, radio, etc.

\section{Media}

"Media" refers to the various means of communication. Communication paves way for distribution of information, activity, education, data, or promotional communication. Media is a combined noun for the press or news reporting agencies. In the computer world, "media" is also used as a collective noun referring to different types of data storage options.

\subsection{Types of mass media}

'Mass media' denotes the communication policy which can be used to interact with a large number of audiences in different languages. It is the most powerful tool of communication which helps promoting the right things at right time and gives a real experience to the group of listeners. News media pertains to print as well as the electronic source, through which people communicate information and news with people. There are three major kinds of news media

- $\quad$ Print Media.

- Broadcast Media.

- New-Age Media.

\subsection{Print media}

Print media encompasses mass communication through printed material. The oldest forms of mass communication are newspapers, magazines, journals, newsletters, and other printed materials. These are jointly known as 'the print media'.

\subsection{Broadcast media}

Broadcast media requires the user to use an electric connection to contact it. It is also known as 'broadcast media' which includes radio, television.

\subsection{New-age media}

New-age media are internet, computers, telephones, etc.

\section{The role of media at the tertiary level}

An rising number of people use an immense deal of time watching television, reading newspapers, magazines, playing records and listening to the radio. In the second language learning, the students need to have enough experience to attain ability of the language. Various media provide pupils an opportunity to get to know the subtle nuances of the foreign language.

Media education is vital as it develops students' imaginative power. Media education deals with film, television press, radio etc. Their impact on the students' improvement is noteworthy. Its aim is to enable students develop thinking, analysing and make them brilliant on their experiences while using various means of media. Mass media provides students with a lot of language activities like using newspapers, magazines, radio, TV, movies, books, Internet etc. and tasks to develop reading, writing, speaking and listening skills. Media provides students with abundant inside and outside classroom activities, promoting general reading. It instils confidence among learners and promotes their ability to continue their reading, even outside the classroom and thereby enhances motivation. The components of mass media used as a teaching device in English Language Teaching classrooms are as follows.

\subsection{Newspaper}

Newspaper can be an important tool for teachers who work with grown up students. Newspaper activities have been expanded in an open learning plan and may be employed for assignments, development of skimming and scanning skills, individual study, development of indexing skills, and different components of writing skills.

\subsection{Radio}

Radio plays a pivotal role in promoting thoughts of pupils by creating images in mind through the power of words that motivates the imagination. Thus, radio can be used in the classrooms as it assists students to encourage their imagination, to say their originality.

Many radio programs supply inputs to language learning. Apart from new information and activity in language classes, radio aids to gain expertise of the language over pronunciation, intonation, the pitch of voice, etc.

\subsection{Television}

Television is an important part of modern life. Most of the parents do not allow their children to watch television. They believe that it affects them in all aspects. They want their children to spend the time largely in reading text books. Television also helps students to gain more knowledge.

It helps them enrich their communication as much as the books do. Moreover, television is a source by which students can learn and be entertained.

It supports students to know about the latest news of their countries and the world. Students can learn about science and geography among other things. Thus, television helps students learn and get information about many things. Television is as imperative as books, if pupils use it in a right way.

\subsection{Internet}

Internet offers opportunities for students to interact $24 \times 7$ with native and non-native speakers across the world. The linguistic nature of online communication is attractive for developing language learning.

It can increase student's motivation which helps pupils and teachers to evaluate and categorize information, to encourage and realize ideas, analyse errors, abstract concepts, analyse perspectives, gather information, work in teams, etc. The internet is a brilliant tool for locating the latest news.

In the present study, a survey is conducted among of college students on the basis of rural and urban areas and was conducted to find out the way, how media enhances the communicative competence among the students on the basis of the four criteria viz. newspaper, radio, television and internet.

The survey was conducted using a questionnaire as a tool to find out how media could be used in enhancing communicative competence of the students of rural and urban areas. A total 50 students from two colleges - one from rural and one from urban 
areas were surveyed with a structured questionnaire consisting of sixteen questions.

\section{Data analysis}

A simple and forward numerical analysis of the data collected exposes interesting and surprising result, which re informative and suggestive of the attitudinal aspects of the students in learning the language. Enough care and caution were taken regarding the locality of the college and the students.

Table 1 indicates that the students of rural areas in general are not good in communicative competence though they thrive hard to achieve excellence.

To the question, whether newspaper improves the reading speed, 4 students observe that they are very much correct, 6 students, for correct, 5 students opted to not always and 7 students opineit is incorrect and 3 students, very much incorrect.

The idea if radio improves good pronunciation, 8 students opine that they very much correct, 5 students feel that they correct, 4 students opted to not always and 3 students have the lowest number opted to be incorrect and 5 students observe that they are very much incorrect.

The opinion that television improves the confidence is well received and 3 students have preferred to remain very much correct, 6 students, to be correct, 4 students have the option not always and 5 students opine that they incorrect and 7 students get very much incorrect.

The question of utilizing internet as an effective tool for enhancing English 4 students have feel that they are very much correct, 6 students, seem to be correct, A highest number of 8 students opine to not always and 5 students remain under the category of incorrect and 2 students have the lowest number of all under that they belong to very much incorrect category.

\begin{tabular}{|c|c|c|c|c|c|c|c|}
\hline \multicolumn{7}{|c|}{ Table 1: Impact of Media on Rural Students } \\
Sl. & $\begin{array}{c}\text { Very } \\
\text { Question } \\
\text { S. }\end{array}$ & $\begin{array}{c}\text { Muc } \\
\text { h } \\
\text { Corr } \\
\text { ect }\end{array}$ & $\begin{array}{c}\text { Corr } \\
\text { ect }\end{array}$ & $\begin{array}{c}\text { Not } \\
\text { Alwa } \\
\text { ys }\end{array}$ & $\begin{array}{c}\text { Incorr } \\
\text { ect }\end{array}$ & $\begin{array}{c}\text { Very } \\
\text { Much } \\
\text { Incorr } \\
\text { ect }\end{array}$ & $\begin{array}{c}\text { Tot } \\
\text { al }\end{array}$ \\
\hline & $\begin{array}{c}\text { Newspap } \\
\text { er } \\
\text { Develops } \\
\text { the } \\
\text { Reading } \\
\text { Speed }\end{array}$ & 4 & 6 & 5 & 7 & 3 & 25 \\
\hline $\begin{array}{c}\text { Radio } \\
\text { Helps to } \\
\text { Acquire } \\
\text { Good } \\
\text { Pronuncia } \\
\text { tion }\end{array}$ & 8 & 5 & 4 & 3 & 5 & 25 \\
\hline & $\begin{array}{c}\text { Televisio } \\
\text { n } \\
\text { Enhances } \\
\text { The } \\
\text { Learners' } \\
\text { Confiden } \\
\text { ce By } \\
\text { Sharpenin } \\
\text { g The } \\
\text { Learning } \\
\text { Skills }\end{array}$ & 3 & 6 & 4 & 5 & 7 & 25 \\
\hline $\begin{array}{c}\text { Internet is } \\
\text { an } \\
\text { Effective } \\
\text { Tool for } \\
\text { Language } \\
\text { Teaching }\end{array}$ & 4 & 6 & 8 & 5 & 2 & 25 \\
\hline
\end{tabular}

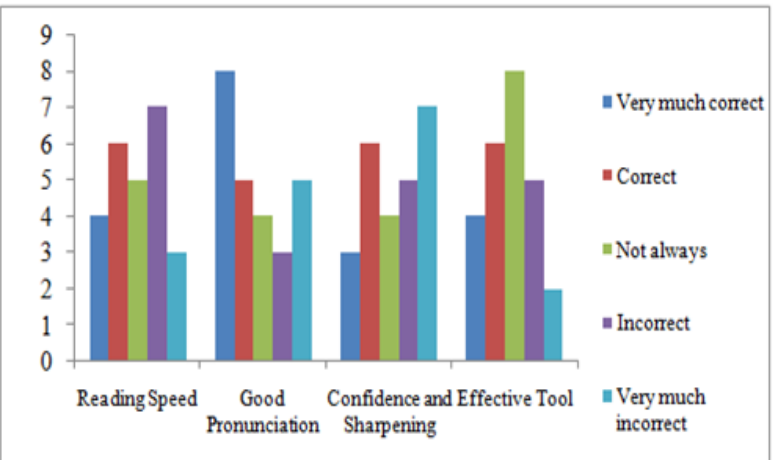

Figure 1: Impact of Media on Rural Students

Table 2: Impact of Media on Urban Students

\begin{tabular}{|c|c|c|c|c|c|c|c|}
\hline $\begin{array}{c}\text { Sl. } \\
\text { No }\end{array}$ & Questions & $\begin{array}{c}\text { Muc } \\
\text { h } \\
\text { Corr } \\
\text { ect }\end{array}$ & $\begin{array}{c}\text { Corr } \\
\text { ect }\end{array}$ & $\begin{array}{c}\text { Not } \\
\text { Alwa } \\
\text { ys }\end{array}$ & $\begin{array}{c}\text { Incorr } \\
\text { ect }\end{array}$ & $\begin{array}{c}\text { Very } \\
\text { Much } \\
\text { Incorr } \\
\text { ect }\end{array}$ & $\begin{array}{c}\text { Tot } \\
\text { al }\end{array}$ \\
\hline $\mathbf{2}$ & $\begin{array}{c}\text { Newspape } \\
\text { r Develops } \\
\text { the } \\
\text { Reading } \\
\text { Speed. }\end{array}$ & 5 & 8 & 3 & 2 & 7 & 25 \\
\hline $\begin{array}{c}\text { Radio } \\
\text { Helps to } \\
\text { Acquire } \\
\text { Good } \\
\text { Pronunciat } \\
\text { ion. }\end{array}$ & 9 & 3 & 6 & 4 & 3 & 25 \\
\hline & $\begin{array}{c}\text { Television } \\
\text { Enhances } \\
\text { the } \\
\text { Learners' } \\
\text { Confidenc } \\
\text { e by } \\
\text { Sharpenin } \\
\text { g the } \\
\text { Learning } \\
\text { Skills. }\end{array}$ & 6 & 5 & 5 & 4 & 5 & 25 \\
\hline $\mathbf{4}$ & $\begin{array}{c}\text { Internet is } \\
\text { an } \\
\text { Effective } \\
\text { Tool for } \\
\text { Language } \\
\text { Teaching. }\end{array}$ & 7 & 8 & 5 & 3 & 3 & 25 \\
\hline
\end{tabular}

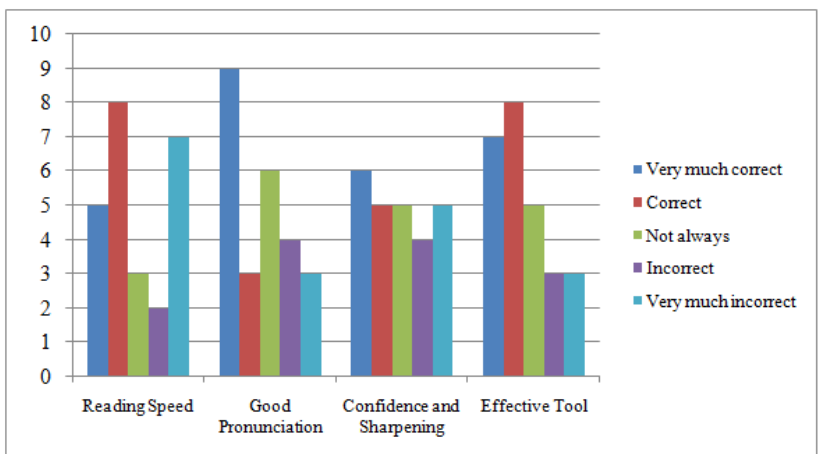

Figure 2: Impact of Media on Urban Students

Table 2 analyses in depth the response of 25 urban area students towards the use of media for the purpose of improving English. The first variable is intended to checkout students' attitude towards using newspaper for boosting communication skills. Out of 25 students, 5 students opt very much correct whereas, 8 students have the highest number and remain correct. 3 students take the option of being not always and 2 students opt to incorrect. 7 students go for very much incorrect. The second variable is intended to checkout students who improve their 
pronunciation; 9 students feel that it is very much correct whereas, 3 students opt correct. 6 students tend to not always and 4 students opine incorrect. 3 students have stated that it is very much incorrect. The third variable is intended to checkout students who boosted their confidence by sharpening the learning skills. 6 students stand at very much correct with the concept whereas, 5 students tend to correct. 5 students take a stance of not always and 4 students opt incorrect. 5 students opt very much incorrect. To the fourth question that internet is an effective tool for language teaching. 7 students agree that it is very much correct whereas, 8 students agree that it is correct. 5 students take the stance of not always and 3 students opine that it is incorrect. 3 students have chosen disagree as they are very much incorrect.

\section{Findings of the study}

The investigation and analysis of the data have shown the following major findings of the study. The remarkable fact the researcher has come across is that the media enabled teaching and also helps to reduce the social disparities among students. They could achieve their common goal of attaining the skills. The study has also exposed how media has significant impact on teachers and how teaching processes have enabled them to plan their lessons and classroom activities successfully and powerfully. They can work in teams and share ideas about the arranged syllabus and curriculum. Many teachers use media to enrich and enhance the traditional teaching learning methods where the students become active speakers rather than being passive listeners.

The other general observations based on the survey conducted are

- Internet connectivity becomes a problem to the students of urban and rural areas.

- No proper facilities to learn English rural area students.

- There is a need to make all the students participate in learning using media as a tool.

- Teachers need to know the use of the media materials.

- Lack of awareness regarding the importance of English.

- Teachers of the colleges located in rural area feel the control in using the media.

- More number of teachers working in urban areas is getting trained for using media than those in rural areas.

- The college in rural areas have no media services as those in urban areas.

- Poor vocabulary habits.

- Lack of trading English newspaper.

\section{Suggestions}

The students favour in terms of time, space, place, content selection and freedom of information. In the past, it was quite impossible to satisfy such requests due to the non-availability of proper tools. Now, it has become feasible and possible to apply open and flexible learning strategies using the media as a tool. With the availability of web tools, it is possible to create contented internet to support learning. Searching, locating and categorizing knowledge and information via internet have opened new vistas to implement flexible learning strategies. There are various applications of the media tools in the teaching and learning system starting from the productivity software to specialized educational software. Hence, research and motivation of teachers to face the challenges of the media enriched teaching is the need of the hour. They need to be aware of the media tools available and sufficient understanding on the combination and use of the tools in teaching. Efforts have to be oriented towards developing positive attitudes regarding the media enabled teaching.

The following remedial measures could be taken to overcome the problems
- Students can be trained to use internet to develop their vocabulary.

- The teachers should nurture new practice as it is the way to enhance the quality of education through communication skills.

- Computer, satellite communication, internet and various electronic media are to be made the real models for teaching and learning.

- Through newspaper reading, learners could get to know many unknown words.

- The teachers need to be supported in meeting the challenge of successfully integrating media in their classroom practices.

- The teachers have to act as role models for prospective learners by using media in their courses.

- The students must be asked to read and speak dialogues to improve their communicative skills.

- The teachers must be taught to have the information and skill to use the digital tools and resources to help all students reach high communicative skills.

- The learners need to listen to the speeches broadcast on radio.

- They can be assigned to read newspaper daily, at least, for an hour.

\section{Conclusion}

The result of the present study reveals that there is a positive impact of media on the four identified components newspaper, radio, television and internet. Moreover the study shows that all the components of educational system perceive media as a useful and friendly tool which has a positive impact on students and education system. A large amount of investigation discover that media has a significant part in making pupil and shaping the personality development skills. It also pointed out that media can improve students' communication, articulation and participation in combined learning. The outcome of the study brings a wider scope for how teachers in schools and college, and learners can get benefits from the use of media for enhancing language skills. It is beyond doubt that media develops communication skills of the students by way of providing information, knowledge, experience, etc. pertaining to language learning. By catering to the needs and demands of the language learners, media as a tool stand a class apart. The result also highlights that media is a valuable input for formulating strategies. The researcher has found that media tools do play effective roles to have a positive effect on urban area students learning outcomes.

\section{References}

[1] Abilasha R \& Ilankumaran M, "Incarnation of ICT in English Language Teaching", Research Journal of English Language and Literature (RJELAL) Vol.2, No.4, (2014), pp.57-65.

[2] Abilasha R \& Ilankumaran M, "New Trends in English Language Teaching. A Novel perspective", International Journal on Studies in English Language and Literature (IJSELL), Vol.2, No.11, (2014), pp.46-52.

[3] Angel JCB \& Ilankumaran M, "Teaching English as a Language for Communication through Different Genres of Literature", International Journal of Multidisciplinary Researches, Vol.4, No.6, (2017), pp.73-76.

[4] Bright C. Technology of Teaching English. ( ${ }^{\text {st }}$ Edition) Chennai: PDR Educational Trust, (2005).

[5] Chomsky N, Aspects of the Theory of Syntax, MIT Press, (1965).

[6] Deepa P \& Ilankumaran M, "Teaching Literature Enhances Communication Skills - A Study with Special Emphasis on Poetry", International Journal of Engineering and Technology (IJET), Vol.7, No.3, (2017), pp.187-191. 
[7] Gogoi G, "Role of Technological Media in English Language Teaching", International Journal of English Language, Literature and Humanities, Vol.3, (2015), pp.57-61.

[8] Goldstein N \& Cialdini R, Scientifically Proven Ways to be Persuasive. NY: First Free Press, (2008)

[9] Venugopalan P \& Ilankumaran M, "Communication Skills in English through Developmental Speaking, Contemporary Discourse", International Journal of Peer-Reviewed, Vol.3, No.2, (2012).

[10] Mahalakshmi, Media for Effective English Language Teaching, ELT Voices-India, Vol.3, No.4, (2013).

[11] Sreena S \& Ilankumaran M, "Types of Communication Skills and the Ways and Means to Enhance Them", International Journal of English Language and Literature in Humanities (IJELLH), Vol.6, No.4, (2018), pp.492-498.

[12] Abilasha R, "Short Stories as a Genre of Literature to Teach Speaking Skills", International Journal on Studies in English Language and Literature (IJSELL), Vol.6, No.1, (2018), pp.25-27.

[13] Abilasha R, "Smart Classrooms: An In-built Innovation of the Millennium English Language Education", International Journal of English Language and Literature in Humanities (IJELLH) with IF 5.7, Vol.6 No.4, (2018), pp.348-355.

[14] Delbio A, "Psychological Influence of Dyslexia and Apraxia Affecting Second Language Acquisition on Young Learners", International Journal of English Language and Literature in Humanities (IJELLH) with IF 5.7, Vol.6, No.4, (2018), pp.81-90.

[15] JeyaGowri K, "Challenges involved in ELT During Transition from Higher Secondary to Tertiary Level", International Journal of English Language and Literature in Humanities (IJELLH) with IF 5.7, Vol.6 No.4, (2018), pp.31-38.

[16] Micah V, "Configuring Theories and Techniques to Minimize Mother Tongue Influence (MTI) in Second Language Classrooms", International Journal of English Language and Literature in Humanities (IJELLH) with IF 5.7, Vol.6, No.4, (2018), pp.17-29.

[17] Jerose Flashan U, "The Objectives of Teaching English as a Second Language at Different Levels of Learning", International Journal of English Language and Literature in Humanities (IJELLH) with IF 5.7, Vol.6, No.4, (2018), pp.39-52.

[18] Vinothees A P, "Importance of Accuracy in Developing English Speaking Skills", International Journal of English Language and Literature in Humanities (IJELLH) with IF 5.7, Vol.6, No.4, (2018), pp.143-151.

[19] Deepa P, “Activity Based Learning Enhances Speaking Skills with Poetry as a Tool", International Journal of English Language and Literature in Humanities (IJELLH) with IF 5.7, Vol.6 No.4, (2018).

[20] Abinisha S, "The Harvest of Humans as Portraryed by Manjula Padmanabhan in Harvest", International Journal of English Language and Literature in Humanities (IJELLH) with IF 5.7, Vol.6 No.4, (2018), pp.338-341.

[21] Abdul Majeed CT, "Teaching English Using Programmed Instruction", International Journal of English Language and Literature in Humanities (IJELLH) with IF 5.7, Vol.6, No.4, (2018), pp.511-521.

[22] Abilasha R, "Fourth World Literature: A mouth Piece of Indigenous Languages", World Literature: A Critical Outlook, (2018), pp.1-6

[23] Delbio A, "English Language: A Tool to Express the Repressed Psyche of the Fourth World", World Literature: A Critical Outlook, (2018), pp.42-45.

[24] Jeya Gowri K, "Prescriptions of Fourth World Elements at the Tertiary Level for Global Acclaim", World Literature: A Critical Outlook, (2018), pp.97-100.

[25] Sreena S, "The Role of Teachers in Developing Second Language Acquisition", International Journal of Research in Humanities, Arts and Science with IF 2.135, Vol.2, No.9, (2018), pp.40-43.

[26] Abilasha R, "English Language Teaching: Challenges and Strategies from the Indian Perspective", International Journal of Engineering and Technology (IJET), Vol.7, No.3, (2018), pp.202-205

[27] Delbio A, "Theories, Techniques, Methods and Approaches of Second Language Acquisition: A Psychological Perspective", International Journal of Engineering and Technology (IJET), Vol.7 No.3, (2018), pp.192-197.

[28] JeyaGowri K, "Application of Theories, Techniques, Methods and Approaches to Develop Second Language Skills - A Study based on Transition from Schooling to College", International Journal of
Engineering and Technology (IJET), Vol.7, No.3, (2018), pp.210-215.

[29] Deepa P, "Teaching Literature Enhances Communication Skills A Study with Special Emphasis on Poetry", International Journal of Engineering and Technology (IJET), Vol.7, No.3, (2018), pp.187-191. 